\title{
POTENSI WISATA ALAM DI KOTA PAGAR ALAM, PROVINSI SUMATERA SELATAN BERDASARKAN PENAWARAN, PERMINTAAN DAN DAYA DUKUNG
}

\author{
(Potential natural tourism in Pagar Alam City, South Sumatera Province based on supply, \\ demand and carrying capacity)
}

\author{
Yogie Zulni Pratama ${ }^{\left.{ }^{*}\right)}$, Rinekso Soekmadi ${ }^{2)}$, Afra DN Makalew ${ }^{3)}$ \\ 1 Program Studi Ilmu Pengelolaan Sumber Daya Alam dan Lingkungan IPB, Gedung Sekolah \\ Pascasarjana Lantai II Kampus IPB Baranangsiang Bogor 16144, Indonesia \\ 2 Departemen Konservasi Sumberdaya Hutan dan Ekowisata IPB, Jl. Raya Dramaga Kampus IPB \\ Dramaga Bogor 16680, Indonesia \\ 3 Departemen Arsitekstur Lanskap IPB, Jl. Raya Dramaga Kampus IPB, Dramaga Bogor 16680, \\ Indonesia \\ *e-mail: yogiezulni.p@gmail.com
}

\begin{abstract}
Pagar Alam City belongs to the administrative region of South Sumatera Province and has a variety of natural tourism to be developed. This research focuses on determining natural tourism potentials based on supply, demand and carry capacity in Pagar Alam City. The assessment used the analysis of potential objects and natural attractions using the guidelines for regional analysis of operations-objects and natural attractions (ADO-ODTWA) from Directorate General of Forest Protection and Nature Conservation (2003) and carrying capacity's analysis using the formula Douglass (1982). The results showed that Pagar Alam city has 7 natural tourism potential dan 29 natural tourism enough potential with the highest potency value index of the Dempo Mountain Tea Plantation Area $87.89 \%$ and the lowest $33.51 \%$ is Blange Water Fall. The number of tourists according to carrying capacity for each tourism activities are recreational activities 1.041 .336 peoplelyear and camping activities 555.685 peoplelyear.
\end{abstract}

Keywords: demand, carrying capacity, natural tourism, supply, tourist.

\section{Abstrak}

Kota Pagar Alam termasuk dalam wilayah Provinsi Sumatera Selatan dan memiliki berbagai wisata alam untuk dikembangkan. Fokus penelitian adalah kajian potensi wisata alam di Kota Pagar Alam, Sumatera Selatan berdasarkan penawaran, permintaan dan daya dukung di Kota Pagar Alam. Penilaian yang digunakan adalah analisis potensi objek dan daya tarik wisata alam menggunakan pedoman analisis daerah operasi-objek dan daya tarik wisata alam (ADOODTWA) Direktorat Jendral Perlindungan Hutan dan Konservasi Alam (2003) dan analisis daya dukung menggunakan formula Douglass (1982). Hasil penelitian menunjukkan bahwa Kota Pagar Alam memiliki 7 wisata alam yang berpotensi dan 29 wisata alam cukup berpotensi untuk dikembangkan dengan indeks nilai potensi tertinggi yaitu Kawasan Perkebunan Teh Gunung Dempo dengan persentase $87.89 \%$ dan terendah $33.51 \%$ yaitu Cughup Blange. Jumlah wisatawan sesuai dengan daya dukung untuk masing-masing kegiatan wisata yaitu kegiatan rekreasi adalah 1.041.336 orang/tahun dan kegiatan wisata 555.685 orang/tahun.

Kata kunci: daya dukung, penawaran, permintaan, wisawatan, wisata alam

\section{PENDAHULUAN}

Industri pariwisata merupakan industri terbesar di dunia dan yang terbesar pula memberi kontribusi dalam pengembangan sektor ekonomi dunia
(Denis, 1994). World Travel and Tourism Council (WTTC) tahun 2019 melaporkan bahwa pertumbuhan pariwisata di Indonesia tumbuh dua kali lebih cepat dari rata-rata global. 
Pertumbuhan sektor Pariwisata di Indonesia tumbuh 7,8 persen pada tahun 2018 atau dua kali lipat rata-rata pertumbuhan dunia sebasar 3.9 persen Pada tahun 2018, sektor pariwisata menyumbangkan 890.428 miliar atau memberikan 6,0 persen dari Pendapatan Domestik Bruto Nasional pada tahun 2018. Pariwisata mengalami tren positif ditandai dengan peningkatan jumlah dan potensi untuk dikembangkan. UndangUndang Nomor 10 tahun 2009 menjelaskan pengelolaan pariwisata bertujuan untuk meningkat pendapatan Asli Daerah. Yanti dan Hadya (2018) mengatakan bahwa ada ikatan yang kuat di antara keduanya retribusi pariwisata dengan peningkatan pendapatan Asli Daerah. Kota Pagar Alam termasuk dalam wilayah administratif Provinsi Sumatera Selatan dan merupakan daerah hulu yang berada pada ketinggian 6003195 mdpl (meter dari permukaan laut) dengan luas wilayah 63.366 hektare yang membuat daerah ini masih begitu sejuk dan masih asri (RENSTRA Dinas Pariwisata Kota Pagar Alam 20172025). Berdasarkan Rencana Induk Pembangunan Kepariwisatan Nasional (RIPPARNAS) tahun 2010-2025, Kota Pagar Alam termasuk ke Kawasan Strategis Pariwisata Nasional. Peraturan Presiden (Perpres) No 13 Tahun 2012 Rencana Tata Ruang Wilayah Pulau Sumatera yang memuat beberapa kawasan prioritas pembangunan pariwisata dengan tema-tema pembangunan berdasarkan kepada karakteristik wilayah masing-masing. Kota Pagar Alam termasuk ke dalam strategi operasional perwujudan kawasan peruntukan pariwisata.

Sektor wisata merupakan sektor penting yang tidak terpisahakan dari Kota Pagar Alam karena telah tertuang di dalam visi dari pembangunan Kota Pagar Alam dari tahun 2005 sampai 2025 yaitu "Pagar Alam sebagai Kota Jasa Berbasis Agrowisata Terdepan di Sumatera Bagian Selatan (SUMBANGSEL) tahun 2025" (RENSTRA BAPPEDA Kota Pagar Alam 2016). Wisata menjadi salah satu sektor yang memiliki kontribusi dalam meningkatkan perekonomian Kota Pagar Alam. Berdasarkan Data dinas Pariwisata Pagar Alam 2018, sektor pariwisata memberikan kontribusi pendapatan daerah sebesar Rp.776.500.000 Juta atau 5,2 persen dari pendapatan asli daerah tahun 2017 (RENSTRA Dinas Pariwisata Kota Pagar Alam 2013-2018). Wisata mencakup banyak hal seperti transportasi, akomodasi, jasa, dan atraksi. Selain itu sektor wisata juga akan meningkatkan peran beberapa sektor pendukung di pemerintahan maupun swasta seperti biro perjalanan wisata, industri kerajianan/cinderamata, objek dan daya tarik wisata, hotel, restoran dan sumber daya manusia (Andayani et al., 2012). Laporan Rencana Induk Rencana Induk Pembangunan Kepariwisataan Daerah (RIPPDA) Kota Pagar Alam tahun 2016 menyatakan destinasi dan prioritas program nampaknya belum banyak yang berhasil diimplementasikan terutama pengembangan diversifikasi produk pariwisata. Meskipun saat ini terdapat cukup variasi daya tarik wisata yang ada di Pagar Alam namun belum 
cukup untuk mendatangkan wisatawan dalam jumlah yang signifikan, khususnya wisatawan mancanegara.

Di satu sisi keinginan Kota Pagar Alam untuk menjadikan wisata sebagai sektor andalan pembangunan, namun di sisi lain upaya-upaya nyata dan terukur yang dilakukan untuk mencapai tujuan tersebut relatif masih sangat terbatas.

\section{METODE PENELITIAN}

\section{Lokasi dan Waktu Penelitian}

Pengambilan data penelitian dilaksanakan mulai Februari sampai April 2020 di Kota Pagar Alam, Provinsi Sumatera Selatan.

\section{Bahan dan Alat}

Bahan yang digunakan dalam penelitian ini yaitu peta administrasi Kota Pagaralam dan peta RTRW Kota Pagar Alam, Alat yang digunakan adalah alat tulis, kamera, GPS, seperangkat komputer yang dilengkapi dengan software ArcGIS.

\section{Pengumpulan Data}

Data yang digunakan berupa data primer dan data sekunder. Data perimer diperoleh melalui pengamatan dan pengecekan langsung di lapangan, serta wawancara dan pengisian kuesioner dengan responden yang berkaitan dengan tujuan penelitian. Data sekunder berupa informasi dan data yang diperoleh dari instansi terkait yaitu Dinas Pariwisata DINPAR dan BAPPEDA Kota Pagar Alam.

\section{Analisis Data}

Memetakan Potensi Wisata Alam berdasarkan Penawaran (Supply) dan Permintaan (Demand)

\section{Potensi Penawaran (Supply)}

Pemetaan potensi wisata alam di Kota Pagar Alam dilakukan dengan studi pustaka dari DINPAR dan BAPPEDA Kota Pagar Alam dan pengamatan lapangan. Pengamatan lapangan menggunakan Pedoman Analisis Daerah Operasi Objek dan Daya Tarik Wisata Alam (ADO-ODTWA) Dirjen PHKA (2003) yang telah dimodifikasi sesuai dengan nilai/skor yang telah ditentukan untuk masing-masing kriteria. Jumlah nilai untuk satu kriteria penilaian ODTWA dapat dihitung dengan persamaan sebagai berikut:

$\mathbf{S}=\mathbf{N} \times \mathbf{B}$

Keterangan :

$\mathrm{S}=$ Skor/Nilai Suatu Kriteria

$\mathrm{N}=$ jumlah nilai unsur-unsur pada kriteria, B = Bobot Nilai

Selanjutnya dilakukan klasifikasi berdasarkan jumlah total dari penilaian. Penentuan selang setiap objek wisata dilakukan dengan cara mengurangi skor tertinggi dengan skor terendah dan membaginya dengan banyaknya kelasifikasi pengembangan. Setelah itu dilakukan penentuan kepotensian berdasarkan indeks kepotensian suatu kawasan sebagai berikut > 66.6\% (potensi dikembangkan), 33.3\%-66.6\% (cukup potensi dikembangkan), $<33.3 \%$ (tidak potensi dikembangkan) (Karsudi et al., 2010)

\section{Potensi Permintaan (Demand)}

Analisis ini dilakukan dengan metode deskriptif. Pengambilan sampel wisatawan dilakukan dengan cara accidental sampling (secara kebetulan), yakni siapa saja wisatawan yang kebetulan ada dan dijumpai dapat diminta pendapat mereka (Morissan, 2015). Metode ini dilakukan karena tidak semua populasi dapat dideteksi dengan jelas dimana mereka berada, sehingga 
jika dalam satu waktu bertemu dengan wisatawan maka dapat langsung diberikan kuesioner atau diobservasi. Analisis permintaan dilakukan dengan pendekatan nilai karakteristik permintaan dan motivasinya (Alikodra, 2012).

Pengambilan jumlah sampel wisatawan yang berkunjung ke Kota Pagar Alam menggunakan rumus Yamane (1967) yaitu :

Keterangan:

$$
\mathrm{n}=\frac{N}{N d^{2}+1}
$$

$\mathrm{n}=$ Jumlah Sampel, $\mathrm{N}=$ Jumlah Populasi $\mathrm{D}=$ Level signifikansi yang diinginkan Menganalisis Daya Dukung Ekologi untuk Pengembangan Wisata Alam di Kota Pagar Alam

Metode yang digunakan untuk menghitung daya dukung ekologi yaitu metode Douglass (1982) dengan memperhitungkan kebutuhan area untuk aktivitas wisatawan berdasarkan faktor pemulihan atau keterbalikan (Turnover Factor/TF). Rumus yang digunakan untuk menghitung daya dukungekologi yaitu sebagai berikut:

$$
A R=\frac{D x \mathrm{a}}{\mathrm{CD} \times \mathrm{TF} \times 43560}
$$

Keterangan:
$\mathrm{AR}=$ Kebutuhan area untuk berwisata pada jenis aktivitas tertentu (acre)
$\mathrm{D}=$ Jumlah wisatawan per tahun (orang)
a $\quad=$ Kebutuhan area wisata $\left(\right.$ feet $\left.^{2}\right)$
$\mathrm{CD}=$ Kapasitas hari pemakaian dalam waktu satu tahun
$\mathrm{TF}=$ Faktor kemampuan alam untuk pemulihan
$43.560=$ Konstanta

\section{HASIL DAN PEMBAHASAN \\ Potensi Penawaran (Supply)}

Perhitungan potensi penilaian penawaran (supply) mengacu kepada pedoman ADO-ODTWA Dirjen PHKA tahun 2003 yaitu penilaian terhadap daya tarik, kadar hubungan/ aksesibilitas, kondisi sekitar kawasan, pengelolaan dan pelayanan, akomodasi, sarana prasarana penunjang, ketersediaan air bersih, Hubungan dengan objek wisata sekitar, keamanan dan pemasaran.

Hasil rekapitulasi perhitungan menunjukkan terdapat 7 objek wisata alam yang berpotensi untuk dikembangkan dengan skor tertinggi 87.89\% yaitu Kawasan Perkebunan Gunung Dempo yang merupakan objek wisata unggulan di Kota Pagar Alam (Tabel 1). 6 objek wisata alam lain yang potensi untuk dikembangkan adalah Green Paradise, Cughup Mangkok, Cughup Embun, Cughup 7 Kenangan, Hutan Bambu dan Puncak Gunung Dempo-Merapi. Selanjutnya ke 29 objek wisata lainnya termasuk dalam kategori cukup berpotensi untuk dikembangkan yang artinya objek wisata ini masih dapat dikembangkan dengan memenuhi syarat-syarat tertentu.

Hasil Perhitungan rekapitulasi ini mengindikasikan bahwa secara umum objek wisata alam di Kota Pagar Alam memiliki potensi yang besar untuk dikembangan sebagai destinasi wisata terutama destinasi wisata alam. 
JURNAL TENGKAWANG (2021)

Vol. 11 (1): 14 - 24

Tabel 1. Rekapitulasi penilaian tingkat potensial wisata alam di Kota Pagar Alam (Recapitulation assessment of the potential level of natural tourism in Pagar Alam City)

\begin{tabular}{|c|c|c|c|c|c|}
\hline No & Objek Wisata & $\begin{array}{c}\text { Total } \\
\text { Skor } \\
\text { ODTW }\end{array}$ & $\begin{array}{c}\text { Nilai } \\
\text { Maksimal } \\
\text { potensi } \\
\text { ODTWA }\end{array}$ & $\begin{array}{c}\text { Indeks } \\
\text { nilai } \\
\text { potensi } \\
\text { dalam } \\
\text { persen }\end{array}$ & Keterangan \\
\hline 1 & Green Paradise & 3835 & 4820 & 74.03 & Potensi \\
\hline 2 & Cughup Pintu Langit & 3595 & 4820 & 63.61 & Cukup Potensi \\
\hline 3 & Cughup Cungkok & 2915 & 4820 & 44.45 & Cukup Potensi \\
\hline 4 & Cughup Mandian & 2915 & 4820 & 44.45 & Cukup Potensi \\
\hline 5 & Cughup Tinggi & 2945 & 4820 & 44.79 & Cukup Potensi \\
\hline 6 & Cughup Ayek Dehas & 3060 & 4820 & 46.20 & Cukup Potensi \\
\hline 7 & Cughup Luang Dangku & 2925 & 4820 & 44.29 & Cukup Potensi \\
\hline 8 & Cughup Ayek Melintang & 2955 & 4820 & 44.62 & Cukup Potensi \\
\hline 9 & Cughup Seluang & 2755 & 4820 & 41.76 & Cukup Potensi \\
\hline 10 & Cughup Lematang & 3615 & 4820 & 61.69 & Cukup Potensi \\
\hline 11 & Sungai Lematang & 3180 & 4820 & 54.58 & Cukup Potensi \\
\hline 12 & Cughup Karang & 2965 & 4820 & 42.81 & Cukup Potensi \\
\hline 13 & Cughup Besemah & 2830 & 4820 & 41.85 & Cukup Potensi \\
\hline 14 & Cughup Ayek Ipo & 2910 & 4820 & 40.70 & Cukup Potensi \\
\hline 15 & Cughup Panorama & 3150 & 4820 & 48.85 & Cukup Potensi \\
\hline 16 & Cughup Anak Lematang & 2630 & 4820 & 37.30 & Cukup Potensi \\
\hline 17 & Lime Stone & 3300 & 4820 & 55.50 & Cukup Potensi \\
\hline 18 & Cughup Napal Kuning & 2865 & 4820 & 40.89 & Cukup Potensi \\
\hline 19 & Cughup Anak Ghuse & 2865 & 4820 & 40.89 & Cukup Potensi \\
\hline 20 & Cughup Anginan & 2740 & 4820 & 39.13 & Cukup Potensi \\
\hline 21 & Cughup Ayek Lempaung & 2405 & 4820 & 33.87 & Cukup Potensi \\
\hline 22 & Cughup Ayek Baghu & 2815 & 4820 & 40.65 & Cukup Potensi \\
\hline 23 & Cughup Belange & 2345 & 4820 & 33.51 & Cukup Potensi \\
\hline 24 & Cughup Mangkok & 3805 & 4820 & 73.83 & Potensi \\
\hline 25 & Cughup Embun & 3735 & 4820 & 70.25 & Potensi \\
\hline 26 & Cughup Tujung Kenangan & 3600 & 4820 & 68.43 & Potensi \\
\hline 27 & Hutan Bambu & 3540 & 4820 & 69.21 & Potensi \\
\hline 28 & Puncak Gunung Dempo-Merapi & 3655 & 4820 & 74.45 & Potensi \\
\hline \multirow[t]{2}{*}{29} & Kawasan Perkebunan Teh Gunung & & 4820 & & \\
\hline & Dempo & 4270 & & 87.89 & Potensi \\
\hline 30 & Cughup Pakis & 3320 & 4820 & 60.57 & Cukup Potensi \\
\hline 31 & Cughup Alap-alap & 3560 & 4820 & 64.68 & Cukup Potensi \\
\hline 32 & Magnet Dempo & 3235 & 4820 & 58.36 & Cukup Potensi \\
\hline 33 & Cughup Rimau & 3190 & 4820 & 58.00 & Cukup Potensi \\
\hline 34 & Danau Muara Tenang & 3125 & 5000 & 52.33 & Cukup Potensi \\
\hline 35 & Danau Gheban & 3550 & 5000 & 66.23 & Cukup Potensi \\
\hline 36 & Danau Mayan & 3235 & 5000 & 62.26 & Cukup Potensi \\
\hline
\end{tabular}




\section{Potensi Permintaan (Demand)}

Karakteristik Wisatawan

Hasil penilaian terhadap 100 responden terpilih menunjukkan bahwa karakteristik wisatawan di Kota Pagar Alam yaitu jenis kelamin perempuan lebih tinggi yaitu $64 \%$ sedangkan laki- laki $36 \%$. Wisatawan yang berkunjung memiliki usia rata-rata $15-35$ tahun dengan persentase mencapai $84 \%$ (Tabel 2). Hal ini diduga karena pada usia itulah orang melakukan berbagai aktifitas dan kegiatan (Yuniarti, 2018).

Tabel 2. Karakteristik wisatawan pada wisata alam di Kota Pagar Alam (ourist characteristics of natural tourism in Pagar Alam City)

\begin{tabular}{|c|c|c|c|}
\hline No & Parameter & Kriteria & total \\
\hline \multirow[t]{2}{*}{1} & Jenis kelamin & perempuan & 64 \\
\hline & & laki-laki & 36 \\
\hline \multirow[t]{3}{*}{2} & Umur & $15-35$ & 84 \\
\hline & & $36-50$ & 15 \\
\hline & & $>50$ & 1 \\
\hline \multirow[t]{3}{*}{3} & Pendidikan & SMP & 1 \\
\hline & & SMA & 31 \\
\hline & & Perguruan Tinggi & 68 \\
\hline \multirow[t]{7}{*}{4} & Pekerjaan & Guru & 16 \\
\hline & & PNS & 22 \\
\hline & & Swasta & 22 \\
\hline & & Pelajar/Mahasiswa & 37 \\
\hline & & Petani & 1 \\
\hline & & Pedagang & 1 \\
\hline & & TNI & 1 \\
\hline \multirow[t]{3}{*}{5} & Asal & Pagar Alam & 71 \\
\hline & & Luas Kota & 27 \\
\hline & & Luar Provinsi & 2 \\
\hline
\end{tabular}

Tingkat pendidikan wisatawan di dominasi hingga perguruan tinggi dengan nilai 68\%. Semakin tinggi pendidikan seseorang semakin tinggi pula keingintahuan mereka tentang pengetahuan dan pemahaman terhadap alam sekitarnya, sehingga akan berpengaruh dan memberikan nilai positif bagi kelestarian alam pada objek yang mereka kunjungi (Yuniarti, 2018). Sedangkan status pekerjaan di dominasi oleh pelajar/mahasiswa dengan nilai $37 \%$. Selanjutnya jika dilihat dari asal tempat tinggal wisatawan menunjukkan bahwa $71 \%$ berasal dari Kota Pagar Alam sedangkan sisanya berasal dari luar kota dan provinsi

\section{Motivasi Wisatawan}

Motivasi terbentuk karena adanya kebutuhan atau keinginan manusia itu sendiri untuk melepaskan diri sejenak dari kegiatan rutin (Yuniarti, 2018). Motivasi wisatawan yang datang ke Kota Pagar Alam (Tabel 3) untuk aktivitas kreasi memiliki persentase $88 \%$, Hal ini dikarenakan Kota Pagar Alam 
merupakan kota wisata yang terkenal akan keindahan wisata alamnya dengan objek wisata unggulan yaitu Gunung Dempo. Motivasi wisatawan selanjutnya berkemah dengan pesentase $8 \%$ dan selanjutnya memancing dengan persentase $4 \%$.

Tabel 3 Motivation wisatawan pada wisata alam di Kota Pagar Alam (Tourist motivation of natural tourism in Pagar Alam City)

\begin{tabular}{clcc}
\hline No & Parameter & Wisatawan & Total \\
\hline 1 & Rekreasi & 92 & 92 \\
2 & Wisata & 8 & 8 \\
\hline
\end{tabular}

\section{Persepsi Wisatawan}

Buaton \& Purwadio (2015) menyebutkan persepsi adalah proses yang digunakan oleh seorang individu untuk memilih, mengorganisasi dan menginterprestasi masukan-masukan informasi guna menciptakan gambaran dunia yang memiliki arti. Persepsi wisatawan dapat diartikan sebagai pengetahuan dan pandangan para wisatawan. Pesepsi wisatawan dapat dilhat pada table 4, dimana pandangan wisatawan terhadap pelayanan pengelolaan menyatakan 39\% cukup baik, $30 \%$ baik, dan $21 \%$ kurang baik.

Table 4. Partisipasi wisatawan pada wisata alam di Kota Pagar Alam (Tourist perception of nature tourism object in Pagar Alam City)

\begin{tabular}{|c|c|c|c|}
\hline No & Parameter & Kriteria & Total \\
\hline \multirow[t]{3}{*}{1} & Pelayanan/Pengelolaan & Baik & 30 \\
\hline & & Cukup Baik & 39 \\
\hline & & Kurang Baik & 31 \\
\hline \multirow[t]{3}{*}{2} & Harga Tiket & Murah & 19 \\
\hline & & Sedang & 57 \\
\hline & & Mahal & 24 \\
\hline \multirow[t]{3}{*}{3} & Kebersihan & Baik & 21 \\
\hline & & Cukup Baik & 60 \\
\hline & & Kurang Baik & 19 \\
\hline \multirow[t]{3}{*}{4} & Keamanan & Baik & 19 \\
\hline & & Cukup Baik & 62 \\
\hline & & Kurang Baik & 19 \\
\hline \multirow[t]{3}{*}{5} & Akomodasi & Baik & 15 \\
\hline & & Cukup Baik & 62 \\
\hline & & Kurang Baik & 23 \\
\hline \multirow[t]{3}{*}{6} & Transportasi & Baik & 14 \\
\hline & & Cukup Baik & 55 \\
\hline & & Kurang Baik & 31 \\
\hline \multirow[t]{3}{*}{7} & Souvenir & Baik & 19 \\
\hline & & Cukup Baik & 52 \\
\hline & & Kurang Baik & 29 \\
\hline
\end{tabular}

Sebanyak $57 \%$ wisatawan mengganggap harga tiket termasuk dalam kategori sedang. Tingkat kebersihan sebesar $60 \%$ dinyatakan cukup baik. Wisatawan yang berkunjung menyatakan bahwa tingkat keamanan cukup baik dengan persentase $62 \%$ dan keadaan akomodasi di objek wisata sebesar $62 \%$ dinyatakan cukup baik. Kemudian para wisatawan menyatakan bahwa transportasi menuju destinasi wisata sebesar $55 \%$ bernilai cukup baik dan untuk kemudahan mendapatkan souvenir cukup baik dengan nilai $52 \%$. 


\section{Harapan Wisatawan}

Harapan adalah apa yang konsumen pikirkan harus disediakan oleh penyedia jasa. Akan tetapi, harapan bukan merupakan prediksi dari apa yang akan disediakan oleh penyedia Harapan merupakan faktor penentu kepuasan konsumen (Handayani et al., 2016). Dalam konteks pariwisata, memahami harapan wisatawan merupakan sesuatu yang sangat penting karena harapan secara signifikan dapat memengaruhi proses pilihan wisata serta pengalaman yang akan dirasakan (Antariksa, 2012). Harapan wisatawan merupakan saran dan keinginan dari wisatawan terhadap kondisi, aksebilitas, fasilitas dan pelayanan di objek wisata alam yang ada di Kota Pagar Alam. Saran dan harapan wisatawan tersebut adalah penambahan jenis atraksi, perbaikan aksesibilitas, penambahan/perbaiakan fasilitas, dan peningkatan pelayanan wisatawan (Tabel 5). Penambahan jenis atraksi memiliki nilai 26\%. Wisatawan menganggap bahwa tingkat penambahan jenis atraksi diperlukan agar wisatawan yang berkunjung ke objek wisata alam dapat melakukan berbagai aktivitas lain selain menikmati pemandangan. Kemudahan aksesibilitas menuju destinasi objek wisata masih kecil yaitu 20\%. Penambahan/perbaikan fasilitas memiliki persentase tertinggi yaitu $40 \%$. Hal ini dapat dimaklumi karena masih banyak objek wisata yang tidak memiliki fasilitas dikarenakan lokasi objek wisata itu yang sulit dijangkau Persentase peningkatan pelayanan wisatawan yaitu sebesar $14 \%$.

Tabel 5. Harapan wisatawan pada wisata alam di Kota Pagar Alam (Tourist Excepctations natural tourism in Pagar Alam City)

\begin{tabular}{clcc}
\hline No & Parameter & Wisatwan & Total \\
\hline 1 & Penambahan jenis atraksi & 26 & 26 \\
2 & Perbaikan Aksesbilitas & 20 & 20 \\
3 & Penambahan/Perbaikan Fasilitas & 40 & 40 \\
4 & Peningkatan Pelayanan Wisatawan & 14 & 14 \\
\hline
\end{tabular}

Daya Dukung Ekologis

Daya dukung merupakan

kemampuan objek wisata alam yang dapat menampung jumlah wisatawan pada luas dan satuan waktu tertentu, dimana batas kehadiran wisatawan dan fasilitas pendukungnya tidak menimbulkan gangguan terhadap lingkungan fisik dan kehidupan masyarakat (Purnomo, 2013). Perhitungan daya dukung dilakukan untuk mengetahui jumlah maksimal wisatawan sehingga akan diketahui ambang batas jumlah maksimum wisatawan untuk mengetahui jumlah pengunjung pada level mana yang efisien (Lucyanti, 2013). Ammar et al., (2011) menyatakan jumlah wisatawan yang melebihi daya dukung dapat dibatasi pada area tertentu untuk mengurangi dampak kerusakan. Castellani dan Sala (2010) menyebutkan aspek penting terkait penilaian daya dukung ekologi wisata alam adalah kompleksitas membuat konsep daya dukung operasional dan menghitung nilainya, kemudian dibandingkan dengan ambang batas yang ditetapkan.

Perhitungan daya dukung ekologis di lakukan di kawasan Gunung Dempo 
secara menyeluruh karena hanya kawasan ini yang memiliki data luas dan tata ruang dengan pengelolaan yang baik. Kawasan Gunung Dempo yang dimaksud yaitu berbagai objek wisata yang termasuk dalam kawasan Gunung Dempo yang meliputi Cughup Mangkok, Cughub Embun, Cughup Tujuh
Kenangan, Hutan Bambu, Puncak Gunung Dempo dan Merapi, dan Kawasan Perkebunan Teh Gunung Dempo. Perhitungan daya dukung ekologi di kawasan Gunung Dempo dilakukan pada dua kegiatan yaitu dan rekreasi dan wisata (berkemah) (Tabel 6).

Tabel 6. Jumlah wisatawan dapat ditampung pada Kawasan Gunung Dempo (The number of tourists can be accommodated in the Mount Dempo area)

\begin{tabular}{|c|c|c|c|c|c|c|c|}
\hline \multirow[t]{2}{*}{ No } & \multirow{2}{*}{$\begin{array}{c}\text { Kegiatan } \\
\text { Wista }\end{array}$} & \multicolumn{4}{|c|}{ Variabel } & \multirow{2}{*}{$\begin{array}{c}\text { Kapasitas } \\
\text { Wisatawan } \\
\text { (Orang/tahun) }\end{array}$} & \multirow{2}{*}{$\begin{array}{c}\text { Kapasitas } \\
\text { Wisatawan } \\
\text { (Orang/hari) }\end{array}$} \\
\hline & & $\begin{array}{c}\mathrm{AR} \\
(\text { acre })\end{array}$ & $\begin{array}{c}\mathbf{a} \\
\left(\text { feet }^{2}\right)\end{array}$ & CD & TF & & \\
\hline 1 & Rekreasi & 96,42 & 726 & 120 & 1,5 & 1.041 .336 & 8678 \\
\hline 2 & $\begin{array}{c}\text { Wisata } \\
\text { (Berkemah) }\end{array}$ & 96,42 & 907 & 120 & 1 & 555.685 & 4631 \\
\hline
\end{tabular}

Berdasarkan perhitungan daya dukung, daya tampung kawasan Gunung Dempo dapat menerima wisatawan 1 041336 orang/tahun untuk kegiatan rekreasi dan kegiatan berkemah sebesar 555685 orang/tahun. Data Kunjugan wisatawan di Kawasan Gunung Dempo selama 5 tahun ini menunjukkan bahawa jumlah kunjungan belum melampaui nilai daya dukung untuk semua aktivitas wisata bahkan bisa dibilang masih sangat jauh. Tentu saja hal ini dikarenakan kunjungan wisatawan yang masih belum terlalu banyak walaupun tiap tahun angka kunjungan wisatawan terus meningkat. Besarnya potensi ODTWA dan belum terlampauinya daya dukung menjadikan kawasan Gunung Dempo ini potensi dikembangkan. Daya dukung merupakan faktor pembatas dalam pengembangan produk wisata, jika daya dukung kawasan Gunung Dempo terlampaui maka akan terjadi kemerosotan sumberdaya, kepuasan pengunjung tidak terpenuhi, dan akan memberikan dampak merugikan terhadap masyarakat, ekonomi dan budaya. Konsep daya dukung sangat diperlukan karena dengan adanya konsep ini diharapkan mampu meminimalkan atau mencegah kerusakan sumber daya alam dan lingkungan (Nugraha et al., 2013). Ribeiro et al., (2011) menyebutkan daya dukung ekologi merupakan alat yang dapat menjaga lingkungan dengan pengelolaan yang tepat dari kegiatan manusia sehingga tidak terjadi peningkatan kapasitas.

\section{KESIMPULAN}

Objek wisata alam yang berpotensi untuk dikembangkan di Kota Pagar Alam yaitu Green Paradise, Kawasan Perkebunan Teh Gunung Dempo, Cughup Embun, Cughup Mangkok, Cughup 7 Kenangan, Puncak Gunung Dempo-Merapi dan Hutan Bambu. Penambahan/Perbaikan fasilitas merupakan faktor tertinggi dari permintaan wisatawan dalam mendukung pengembangan wisata alam di Kota Pagar Alam. Jumlah wisatawan 
dapat ditampung di Kawasan Gunung Dempo yaitu 1.041.336 orang/tahun untuk kegiatan rekreasi dan 555.685 orang/tahun untuk kegiatan berkemah

UCAPAN TERIMA KASIH/ ACKNOWLEDGEMENT

Penulis mengucapkan terimakasih kepada pihak Dinas Pariwisata Kota Pagar Alam, Dinas Badan Perencanan dan Pembangunan Daerah Kota Pagar Alam, serta Dinas Kesatuan Bangsa dan Politik yang sudah memberikan izin untuk melakukan penelitian di Kota Pagar Alam, dan kepada seluruh responden yang telah meluangkan waktu guna membantu peneliti dalam penelitiannya.

\section{DAFTAR PUSTAKA}

Alikodra, H.S. 2012. Konservasi Sumberdaya Alam Dan Lingkungan. Pendekatan Ecosophy Bagi Penyelamatan Bumi. Yogyakarta (ID): UGM Press.

Ammar MSA, Hassanein M, Madkour HA, Abd-Elgawad AA. 2011. Site Suitability to Tourist Use or Management Programs South Marsa Alam, Red Sea, Egypt. Nusantara Bioscience, 3(1),36-43. Andayani., Sriyanti., Anwar., Ruslin., \& Antariksa. 2012. Pengembangan Kawasan Wisata Balekambang Kabupaten Malang. Jurnal Rekayasa Sipil, 6(2),168-178.

Antariksa B. 2012. Peluang Dan Tantangan Pengembangan Kepariwisataan Di Indonesia. Makalah Sosialisasi Dan Gerakan Sadar Wisata. Solok: Pusat Penelitian Dan Pengembangan Kepariwisataan Kementrian Kebudayaan Dan Pariwisata.

Basiya R, Rozak HA. 2012. Kualitas Daya Tarik Wisata, Kepuasan dan
Niat Kunjung Kembali Wisatawan Mancanegara Di Jawa Tengah. Jurnal Ilmiah Dinamika Kepariwisataan, 11(2),1-12.

Buaton KWS, Purwadio H. 2015. Kriteria Pengembangan Kawasan Wisata Danau Toba Parapat, Sumatera Utara. Jurnal Teknik ITS, 4(1),1-5.

Denis LF. 1994. First Class An. Introduction To Travel \& Tourism. New York (UK): Mcgraw-Hill International Edition.

[Dirjen PHKA] Direktorat Jendral Perlindungan Hutan Dan Konservasi Alam. 2003. Pedoman Analisis Daerah Operasi Objek Dan Daya Tarik Wisata Alam. Bogor (ID). Dirjen PHKA.

Douglass RW. 1982. Forest Recreations, Third Edition. New York (US): Pergamon Press Inc.

Handayani BR, Rusdan H, Sagir HJ. 2016. Faktor Pembentuk Harapan Wisatawan; Sebuah Perspekti Lintas Budaya (Studi Pada Wisatawan Perancis, Australia, Dan Nusantara Yang Berkunjung Di Pulau Lombok). Jurnal Riset Manajemen, 16(1).

Karsudi, Soemadi R, Kartodihardjo H. 2010. Strategi pengembangan ekowisata di Kabupaten Kepulauan Yapen Provinsi Papua. Jurnal Manajemen Hutan Tropika, (3), 148-154.

Lucyanti S, Hendrarto B, Izzati M. 2013. Penilaian Daya Dukung Wisata di Objek Wisata Bumi Perkemahan Palutungan Taman Nasional Gunung Ciremai Provinsi Jawa Barat. Jurnal Pengelolaan Sumber Daya Lingkungan, 1(2), 232-240.

Morissan. 2015. Metode Penelitian Survei. Jakarta (ID). Prenadamedia. 
Nugraha HP. Indarjo A, Helmi M. 2013. Studi Kesesuaian dan Daya Dukung Kawasan untuk Rekreasi Pantai di Pantai Panjang Kota Bengkulu. Jurnal of Marine Research, 2(2), 130-139.

Pearce DG. 1989. Tourist Development. Harlow (UK). Longman Group UK Limited.

[Perpres] Peraturan Presiden. 2012. Peraturan Peresiden No 13 Tahun 2012 Tentang Rencana Tata Ruang Wilayah Pulau Sumatera. Jakarta (ID). Perpres.

Purnomo H. 2013. Kajian Potensi dan Daya Dukung Ekowisata di Kawasan Cagar Alam Pulau Sempu Jawa Timur. [Tesis]. Bogor: Institut Pertanian Bogor.

Rangkuti F. 2005. Analisis SWOT Teknik Membedah Kasus Bisnis. Jakarta (ID): PT. Gramedia Pustaka Utama.

[RENSTRA BAPPEDA]. Rencana Strategis Badan Perencanaan Pembangunan Daerah Kota Pagar Alam Tahun 2013-2018 (ID): BAPPEDA.

[RENSTRA Dinas Pariwisata]. Rencana Strategis Dinas Pariwisarta Kota Pagar Alam Tahun 2013-2018 (ID): Dinas Pariwisata.

Ribeiro MF, Ferreira JC, Silva CP. 2011. The Sustainable Carrying Capacity as A Tool for Environmental Beach Management. Journal of Coastal Research, (64), 14411414.

[RIPPARNAS] Rencana Induk Pembangunan Kepariwisataan Nasional Tahun 2010-2025 (ID): Kemenpar.

[RIPPDA] Rencana Induk Pembangunan Daerah Kota Pagar Alam Tahun 2013-2018 (ID): BAPPEDA.

[UU] Undang-Undang RI. 2009. Undang-Undang No. 10 Tahun
2009 Tentang Kepariwisataan. Jakarta (ID). Kemenpar.

[WTTC] World Travel And Tourism Council. 2019. Travel \& Tourism Economic Impact 2019 World (UK): London.

Yanti N, Hadyah R. 2018. Kontribusi SEKTOR Pariwisata Terhadap Peningkatan PAD Kota Padang. $J$ Benefita, 3(3), 370-379.

Yuniarti E. 2018. Model Pengembangan Ekowisata Heart Of Borneo Di Wilayah Kabupaten Kapuas Hulu Probinsi Kalimantan Barat [Disertasi]. Bogor: Sekolah Pascasarjana, Institut Pertanian Bogor. 